\title{
ACTIVITIES OF THE SOCIETY DURING THE PAST YEAR
}

\author{
Liason Affairs Committee
}

\section{Revision of Constitution}

The year 1975 was marked particularly for the society not only by the fact that it was the year of the quarter century from the foundation, but also by the re-modeling and renewal of its constitution after years' survey, discussion, sometimes argument and agreement as well as disagreement among the members of the society so genuinely expressed that the society will be developed and improved further parallel to the time passing year after year.

In relation to the constitution, the highlights are: (a) the executive committee members nominated by the president no longer exist and all members should be elected by voting, (b) the council members are elected by vote from both its 30 local societies as well as from 11 research divisions of the society accoording to the size of the membership of the local societies and two from research divisions, and (c) more emphasis was placed on the principles of democracy in its administration.

The new constitution was enacted since September 19, 1975, when the 26th convention in Nara Prefecture organized by the Nara local society was staged at Tenri University, one of the oldest capitals of Japan, and the election of the new officials was begun in January, 1976 in order to initiate the activities of the society under the new constitution after the 27th convention and assembly at the Tohoku University in August, 1976 in Sendai City, organized by Miyagi local society.

\section{The 26th Convention in Tenri City}

Out of neary 4,000 members of the society, more than 2,500 mambers and observers joined in the convention, while approximately 1,000 perticipated to the assembly. The convention was pariculary accentuated by: (a) the task research report sessions, (b) the symposia of research divisions, (c) the exhibition of books, facilities and equipment for the research, and (d) the special program on Noh, Gagaku, and Bugaku; Japanese classic arts, music back to the 5 th century.

There were 586 research reports in addition to those in the above, and all these were classified into 11 divisions and reported at 15 different rooms for three days, each report allowed for 15 minutes inclusive of 5 minutes discussion under two chairmen presiding. An increase of 100 papers compared to the last convention was noted despite that the time and period of the convention was changed to more than one month earlier. 


\section{The 27th Convention in Sendai City}

For 55 special foreign members of the society, more participation has been expected for the next convention, and also the convention after next has been decisive to be held in Yamanashi City in 1977 to welcome those from abroad in addition to the invited guest from AAHPER under the bi-societal exchange program since 1973.

\section{Subscription of Research Journal of Physical Education}

The society publishes the journal of 6 volumes yearly inclusive of one English edition so far charging only $\$ 104 . \mathrm{s}$. with the postal charge requested according to the global locality, and all other issues are also with English resumes. Upon the application for the membership to the society, anyone can subscribe to the journal and be provided all the informations of the society.

\section{Governmental Research Grants and Science Council of Japan}

In the Science Council of Japan consisting of 210 members from all the academic fields divided into 7 divisions, the Physicol Fitness Sciences Section under the Biological Sciences Reserach Board was established for the first time in the 7th division, Medical Sciences, in this fiscal year, while that for the physical education will be also structured later in the Ist division, Humanity, Social Sciences and Literatuses, undes the Pedagogical Sciences Board, represented by prof. T. Meshizuka of Tokyo Metropoliten University and Prof. T. Mizuno of Tokyo University, who was to by society sent to AAHPER this year in April to greet the convention held in Milwaukee.

Dr. L.E. Alley of the University of Iowa, ex-president of AAHPER visited the society in May and gave lectures in Tokyo. Dr. R. J. Shephard of University of Tronto, the president of American College of Sports Medicine also visited Japan and greeted the society in December, 1975.

The governmental grants of research were awarded to 51 research projects which amounted to $¥ 43,910,000$, about $\$ 147,000$ u.s. in 1975 for the members of the society, which is 13 percent increase than 1974 .

\section{Task Research}

Three themes were selected to carry out officially in these three years to follow for the purpose of reviewing the all the researches of the society since its foundation in 1950 . The themes are: (1) Future Professional Training in Physical Education upon the Review of Accumulated Researches, (2) New Research Tasks, viewed from the Research Products in the past quarter century, (3) Research Products on Physical Fitness and New Tasks, chaired by Prof. M. Maekawa, Prof. H. Suetoshi, and Prof. H. Matsui respectively. 


\section{Appreciation to Foreign Colleagues}

The society again owes to a great extent to many of foreign societies during the past years both privately and officially. To cite some of them, a group of 21 members was invited by the People's Republic of China in August, 1974 led by Prof. M. Maekewa for 2 weeks, another group of 15 visited Moscow for ICSPE/UNESDO meetings and scientific congress in November, 1974 led by Prof. T. Meshizuka, and the group led by Prof. S. Abe in August, 1975 and many others including those invited by the Chinese society and government participated to APCHPER (Asia-Pacific Congress of Health, Physical Education and Recreation). held in Taipei, the Republic of China.

The Canadian Society with the support by Quebec government invited Prof. T. Meshizuka as one of the international advisors of ICPAS (International Congress of Physical Activity Sciences) to be held in July, 1976,

\section{The Society Sponsored a Group Tour to ICPAS in Quebec}

The society agreed that Japanese Union of Sports Sciences to sponsor the tour to ICPAS in July, 1976, and the travel agent to be Japan Travel Bureau also, with such other similar professional organizations in Japan as Japanese Association of University Physical Education and Sports (JAUPES), Japan Association of Physical Education for Women (JAPEW), and Japanese Society of Physical Fitness and Sports Medicine.

\section{The ICSPE Official Confirmation with the Society Desired for 1978 History Meeting in Japan}

The society has not been officially informed as to the history meeting so far at all, and wishes that it would be so arranged that the meeting to be held objectively. It is, therefore, expected that ICSPE/CIEPS should take its bona fide procedures towards the society if the meeting to be carried on with its co-sponsorship. 